\title{
Identification of Cyanobacteria in a Eutrophic Coastal Lagoon on the Southern Baltic Coast
}

\author{
Martin Albrecht ${ }^{1 *}$, Thomas Pröschold ${ }^{2}$ and Rhena Schumann ${ }^{3}$ \\ ${ }^{1}$ Applied Ecology and Phycology, University of Rostock, Rostock, Germany, ${ }^{2}$ Research Institute for Limnology, University of \\ Innsbruck, Mondsee, Austria, ${ }^{3}$ Applied Ecology and Phycology, Biological Station Zingst, University of Rostock, Rostock, \\ Germany
}

OPEN ACCESS

Edited by:

Feng Chen,

University of Maryland Center for Environmental Sciences,

United States

Reviewed by:

Markus V. Lindh,

Lund University, Sweden Antonio Quesada,

Universidad Autónoma de Madrid,

Spain

${ }^{*}$ Correspondence:

Martin Albrecht

martin.albrecht@uni-rostock.de

Specialty section:

This article was submitted to

Aquatic Microbiology,

a section of the journal

Frontiers in Microbiology

Received: 23 December 2016

Accepted: 08 May 2017

Published: 29 May 2017

Citation:

Albrecht M, Pröschold T and Schumann R (2017) Identification of Cyanobacteria in a Eutrophic Coastal Lagoon on the Southern Baltic Coast. Front. Microbiol. 8:923. doi: 10.3389/fmicb.2017.00923
Cyanobacteria are found worldwide in various habitats. Members of the picocyanobacteria genera Synechococcus and Prochlorococcus dominate in oligotrophic ocean waters. Other picocyanobacteria dominate in eutrophic fresh or brackish waters. Usually, these are morphologically determined as species of the order Chroococcales/clade B2. The phytoplankton of a shallow, eutrophic brackish lagoon was investigated. Phytoplankton was dominated by Aphanothece-like morphospecies year-round for more than 20 years, along a trophy and salinity gradient. A biphasic approach using a culture-independent and a culture-dependent analysis was applied to identify the dominant species genetically. The 16S rRNA gene phylogeny of clone sequences and isolates indicated the dominance of Cyanobium species (order Synechococcales sensu Komárek/clade C1 sensu Shih). This difference between morphologically and genetically based species identifications has consequences for applying the Reynolds functional-groups system, and for validity long-term monitoring data. The literature shows the same pattern as our results: morphologically, Aphanothece-like species are abundant in eutrophic shallow lagoons, and genetically, Cyanobium is found in similar habitats. This discrepancy is found worldwide in the literature on fresh- and brackish-water habitats. Thus, most Aphanothece-like morphospecies may be, genetically, members of Cyanobium.

Keywords: Cyanobacteria, Aphanothece, Cyanobium, lagoon, brackish water, phytoplankton, 16S rRNA

\section{INTRODUCTION}

Cyanobacteria live in most habitats worldwide and are important primary producers. Cyanobacteria often dominate the phytoplankton under meso- or eutrophic conditions. Extensive summer blooms are well known from the Baltic Sea (Wasmund, 1997; Stal et al., 2003) and freshwater lakes (Komárková-Legnerová and Cronberg, 1994; Willame et al., 2005; Michalak et al., 2013). Very small single-cell cyanobacteria $(<2 \mu \mathrm{m}$; picocyanobacteria $=$ APP $)$ are most abundant in the oligotrophic open oceans. Most of these are assigned as species of Synechococcus and Prochlorococcus (Chisholm et al., 1992). Other, but closely related, Synechococcus-like cyanobacteria succeed in eutrophic coastal waters (Caroppo, 2015 and references therein). The brackish waters are relatively little investigated so far (Celepli et al., 2017), but also show high abundances of APP and colonies with cells $<2 \mu \mathrm{m}$. Thus, different cyanobacteria inhabit and can sometimes dominate almost all aquatic systems, even under highly contrasting conditions. Interestingly, most of these cyanobacteria are only assigned as Synechococcus-like organisms, knowing that the genus Synechococcus is polyphyletic (see Komárek et al., 2014 and references therein). 
Monitoring programs target cyanobacterial blooms especially, because of their potential toxicity and high biomass following eutrophication (HELCOM, 1988). The degradation of the bloom biomass may deplete oxygen, and diazotrophic cyanobacteria have a strong influence on nutrient cycles (Larsson et al., 2001). Up to the present, monitoring by environmental agencies has relied on determinations based on morphotypes. Monitoring within the Baltic Sea region refers to two databases: AlgaeBase ${ }^{1}$ (Guiry and Guiry, 2016. AlgaeBase. World-wide electronic publication, National University of Ireland, Galway) and WoRMS World Register of Marine Species² (WoRMS Editorial Board, 2016). One drawback of the WoRMS database is its focus primarily on marine species, which may not cover all species of brackish systems. Another problem in using these databases is that they may not be congruent with the most recent taxonomic results.

In some shallow turbid waters, cyanobacteria produce high and stable biomasses, which maintain poor underwater light availability. Examples of these aquatic systems include two lagoons in the northern Adriatic (Sorokin et al., 2004, 2006), Laguna Chascomús in Argentina (Iachetti and Llames, 2015) and the Curonian Lagoon in the southern Baltic (Olenina, 2013). Two German Baltic lagoons are the Darß-Zingst Bodden chain (DZBC) and the inner Rügenian Bodden (Figure 1), which are also dominated by very small, coccoid and gelatinous colony-forming cyanobacteria (Schumann et al., 2001). Even these very small non-heterocytous picocyanobacteria can be capable of nitrogen fixation, e.g., Aphanothece (Singh, 1973; Bergmann et al., 1997). However, the colonies of very small cells, solitary cyanobacteria and green algae in the picoplankton range $(<2 \mu \mathrm{m})$ are often overlooked or may be assigned to the wrong taxonomic groups.

In accordance with morphological data, i.e., solitary rod-shaped cyanobacteria $<2 \mu \mathrm{m}$ in length, the genera Synechococcus and Prochlorococcus were found using molecular approaches in picoplankton-dominated waters (Chisholm et al., 1992; Robertson et al., 2001; Rocap et al., 2003; Chen et al., 2006; Caroppo, 2015). Geiß et al. (2004) also found Synechococcus 16S rRNA gene sequences in the DZBC, rather than Aphanothece sequences as suggested by morphology. Therefore, the identity of the most abundant cyanobacteria remained uncertain.

The identification of cyanobacteria based on morphology is dependent on easily visible features that are easy to recognize, even at lower magnifications with light microscopy. This is often very difficult, especially for groups without such features and with small cell sizes. In addition, often very little is known about their phenotypic plasticity. For example, in picocyanobacteria, unicellular specimens smaller than $2-3 \mu \mathrm{m}$ were assigned as species of Synechococcus or Cyanobium, whereas specimens in the same size range forming colonies and mucilage were identified as species of Aphanothece, Aphanocapsa or Anathece. Jezberová and Komárková (2007a) and Huber et al. (2017) demonstrated that Cyanobium species can form colonies under grazing pressure,

${ }^{1}$ www.algaebase.org

${ }^{2} \mathrm{http}: / /$ www.marinespecies.org which then morphologically resemble Anathece. Komárek et al. (2011) confirmed that these two genera are closely related, based on 16S rRNA phylogeny.

Only a few morphological features at the cellular level are characteristic for the basal orders Gloeobacterales and Synechococcales, but also occur in Chroococcales (Komárek et al., 2014). This leads to confusion in the identification of simple coccoid cyanobacteria. Species of higher orders have a wider morphological plasticity and can show special features such as branched trichomes, heterocytes or akinetes (Komárek et al., 2014). Many species of simple coccoids cannot be identified by light microscopy, so there may be an enormous cryptic diversity (Komárek et al., 2014) or mis-interpreted results. Therefore, it is not possible to form conclusions on the capabilities of cyanobacterial communities based on morphology alone (Tanabe et al., 2009; Palinska and Surosz, 2014; Komárek, 2016).

To solve this problematic situation in cyanobacteria, molecular data have been used to determine cyanobacteria (e.g., Palinska and Surosz, 2014); however, sequencing is not common practice in monitoring by environmental agencies because of lack of facilities and financial support. In contrast, the scientific communities have the facilities and perhaps the finances to perform the sequencing, but do not have the ability to practice this at larger scales.

Therefore, the aim of this study was to connect the scientific with the applied standards, to address both communities and to provide solutions for filling this gap, e.g., acknowledging both the microscopy and the genetic determination via polyphasic approaches. We identified the dominant planktonic cyanobacteria of the DZBC, using both culture-dependent and -independent approaches. The following questions were addressed: (i) Which genetic lineages of cyanobacteria dominate in the DZBC? (ii) Do the long-term monitoring data reflect the genetic data? (iii) What do the findings mean for monitoring data from other lagoons? To answer these questions, we wanted to determine isolates by both morphological and molecular genetic methods, to acquire a deeper insight into the phylogeny of the dominant organisms. From the results, we hoped to obtain some information about the influence of these organisms on the ecosystem, as well as on the applicability of the Reynolds functional classification of freshwater phytoplankton (Reynolds et al., 2002), which is a standard tool for microscopy-based classification.

\section{MATERIALS AND METHODS}

\section{Sampling Site, Collecting, Culture and Microscopy}

The sampling site was the Darß-Zingst Bodden Chain (Figure 1), a brackish lagoon system of four basins linked by narrow streams, with both a salinity gradient (2-12) and a trophy gradient. Phytoplankton samples have been counted for one site (Zingster Strom) since 1991 at weekly (summer) to biweekly (winter) intervals. Additional samples from the trophy gradient are investigated occasionally (1996: Schumann et al., 2001, 2006; this study, 2015: not yet available). Therefore, the annual cycle 


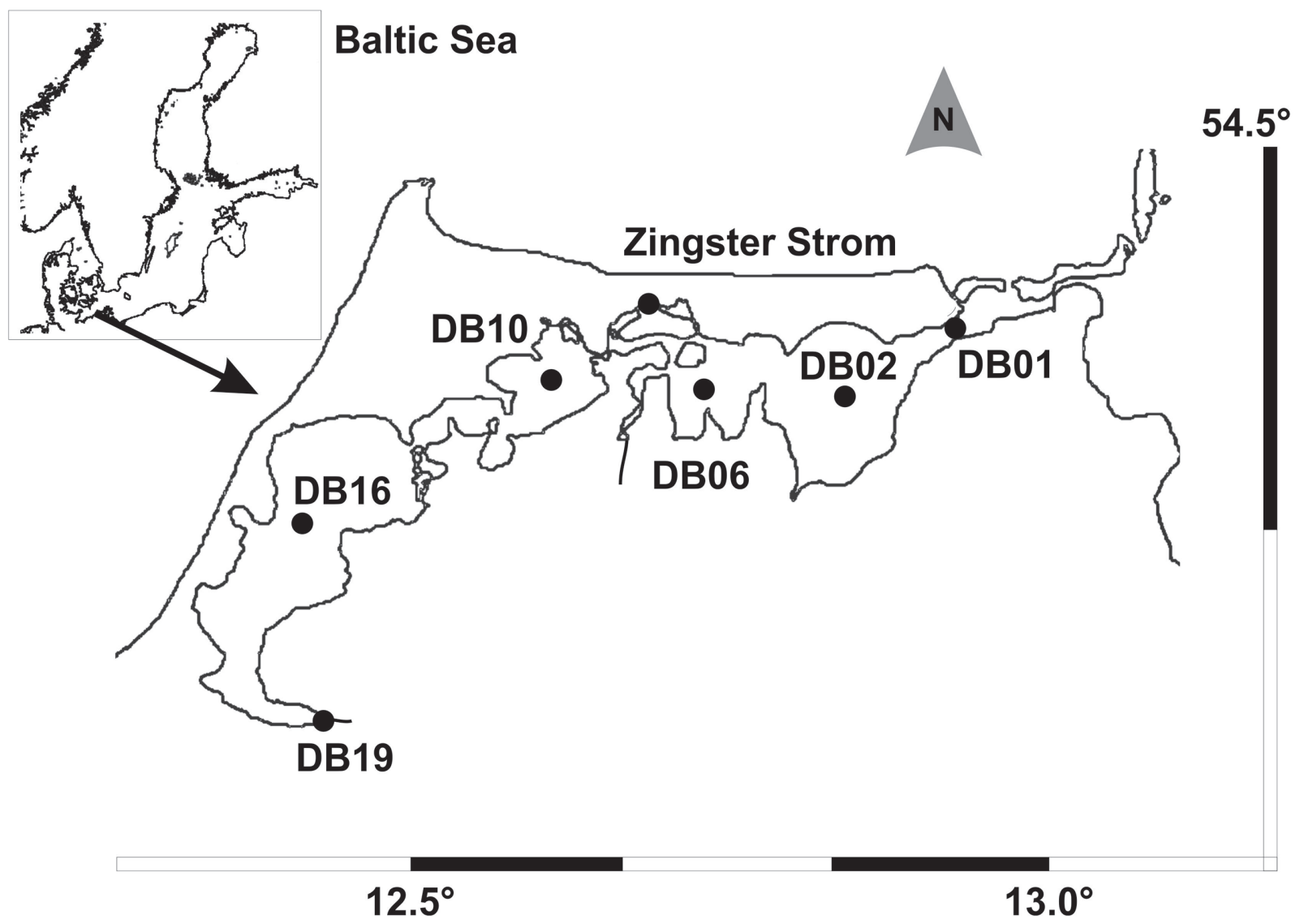

FIGURE 1 | Inner coastal lagoon system Darß-Zingst Bodden Chain with the sampling stations (modified from Schumann et al., 2006).

of the Zingster Strom is given for 2006, for comparison with the species composition in the trophy gradient from the same year. Samples for molecular analyses were taken in spring 2013 at the Zingster Strom. Spring phytoplankton biomass and composition was estimated for 11 samples.

The Zingster Strom is a eutrophic site between the two innermost water basins, with an average salinity of 5.6 (Schumann et al., 2006) and high turbidity. In 2006, salinity was 5.3, near the long-term average. The mean salinity in 2013 was below average, 4.8 (unpublished data). During sampling in April and May 2013 (clones, most of the isolates), salinity ranged from 2.8 to 5.9. This was a period with no extreme values. The water column was always well mixed, and the samples were taken at the water surface. Five hundred milliliter was concentrated by centrifugation at 10,000 rpm (BiofugePico, Heraeus) to $2 \mathrm{ml}$ for DNA extraction (see below). Samples for cell counts were fixed with Lugol (5 drops per $20 \mathrm{ml}$ ) and stored in darkness. Samples for epifluorescence microscopy were

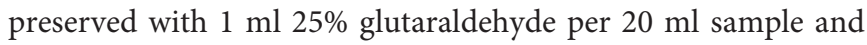
stored refrigerated.

Uni-cyanobacterial cultures were established directly from the plankton samples. First, $200 \mu \mathrm{l}$ of the Bodden sample was plated on BG11 (Rippka and Herdman, 1992) soft agar plates $\left(0.75 \% \mathrm{w} / \mathrm{v}\right.$ agar, Difco $\left.{ }^{\circledR}\right)$ and incubated for 4 weeks at $20^{\circ} \mathrm{C}$ with a light:dark cycle of 16:8 h at $40 \mu \mathrm{mol}$ photons $\mathrm{m}^{-2} \mathrm{~s}^{-1}$ (Osram Lumilux Deluxe Daylight). The plates were checked weekly under a binocular stereomicroscope (Olympus SZ40). Colonies growing on the plates were distinguished by color, then isolated with a sterilized toothpick and transferred to new agar plates. Upon transfer into liquid medium, the samples were checked again, using a light microscope (Olympus BX-51) with a magnification of up to $100 \times$. Microphotographs were taken with a $100 \times$ oil immersion objective, Colorview12 camera and AnalySiS (Soft Imaging Solutions, Olympus), and later with the Olympus UC-30 camera and CellSens Entry software package (Olympus). Colonies were stained with India Ink to observe mucilage. Phytoplankton and isolates were determined using mainly the Süßwasserflora von Mitteleuropa 19/1-3 (Komárek and Anagnostidis, 1999, 2005; Komárek, 2013). Additionally, the Algenflora der Ostsee (Pankow, 1990) was used as a local taxonomic key. All species names were checked for current status and names.

\section{Cell Counts}

Small cyanobacteria were investigated by epifluorescence microscopy. Subsamples of $0.5-1 \mathrm{ml}$ were filtered $(-100 \mathrm{mbar}$ ) onto Irgalanblack stained polycarbonate Track-Etch membranes (Sartorius, $0.2 \mu \mathrm{m}, 25 \mathrm{~mm}$ ). They were mounted with $1 \mathrm{ml}$ 
DAPI solution (freshly filtered through $0.2 \mu \mathrm{m}$ cellulose acetate, $92 \mu \mathrm{mol} \mathrm{DAPI} 1^{-1}$ in phosphate buffer $\mathrm{pH}=7.6$ ) for $5 \mathrm{~min}$. The stain was removed also by filtration and the filter was mounted between a slide and cover slip with thin layers of immersion oil (Olympus, fluorescence-free). DAPI staining would not have been necessary for counting only cyanobacteria, but the same filters were used for heterotrophic bacteria (not shown here). However, some samples showed only weak autofluorescence (mostly in May and June), where the cells were also checked under UV excitation (U-MWU2).

Usually, the green excitation filter cube (U-MWG2) was used (Olympus BX51, UPlan FL 100 NA 1.3 oil objective). At least 200 cells were counted per filter (in at least 20 ocular grids of $10,000 \mu \mathrm{m}^{2}$ ) resulting in a confidence range of $\pm 14 \%$ (Poisson distribution). Regularly, replicate filters were checked and the standard deviation was $<20 \%$. Several colony types were checked for cells per colony. The "Aphanothece" complex unites all colonies with rod-shaped cells, e.g., Cyanodictyon, Cyanonephron, Lemmermaniella and Aphanothece in the sense of morphotypes. The complex of Snowella and Woronichinia (formerly Gomphosphaeria) contains all colonies of larger (>2 $\mu \mathrm{m}$ diameter) cells of spherical or ovoid shape with gelatinous stalks. Ten colonies per sample were counted for their cells. The average (median) cell number per colony was calculated for monthly averages (Zingster Strom, $n_{\text {colony }}=30-$ 40 ) or for quarters (all other sites, $n_{\text {colony }}=30$ ). Total cells were calculated by multiplying colony number with average cells per colony.

Colonies and eukaryotic phytoplankton was counted in sedimentation chambers (volume $1 \mathrm{ml}$, depth $3 \mathrm{~mm}$ ) under a laboratory light microscope (Euromex) at a magnification of $256 \times(16 \times$ oculars and $16 \times$ objective $)$. At least 18 ocular grids of $0.36 \mathrm{~mm}^{2}$ were counted along the chamber diameter. More than 100 individuals were counted for 3 dominant species. Alternatively, $>500$ individuals were counted in total if there were not enough dominant species (Helcom, Combine manual). Replicate counts were not done. Cell sizes of small cyanobacteria were determined by scanning electron microscopy after criticalpoint drying, filament width was measured in fresh samples by image analysis. Filament lengths were all measured upon counting. Larger eukaryotes, especially diatoms, were counted in size classes.

\section{Molecular Analyses}

DNA was extracted from isolates with the Qiagen DNeasy Plant Mini Kit following the manufacturer's manual. The only changes in the protocol were a longer period $(1 \mathrm{~h})$ on the heating block, and omission of a second elution step. The time on the heating block was increased to obtain larger amounts of DNA.

For clone libraries, the 16S rRNA gene of the extracted DNA from the whole DZBC samples was amplified in a PCR reaction using the primers CYA106F and CYA781R (Nübel et al., 1997) for clone libraries. The PCR products of the isolated strains were amplified using the Qiagen Taq-polymerase Master Mix and cyanobacteria-specific primers (SSU-4-forw and CPL-10R; Wilmotte et al., 1993; Marin et al., 2005). For both PCRs a Biometra Thermocycler was used, with the following program:
3 min initial denaturation at $96^{\circ} \mathrm{C}$ followed by 30 cycles of $1 \mathrm{~min}$ at $96^{\circ} \mathrm{C}$ (denaturation), $2 \mathrm{~min}$ at $55^{\circ} \mathrm{C}$ (annealing), $3 \mathrm{~min}$ at $68^{\circ} \mathrm{C}$ (elongation), and a final elongation step of $10 \mathrm{~min}$.

A subsample of the PCR products of isolates and clones was checked for bands via gel electrophoresis on 2\% Agarose (Biozym) gels. Gel electrophoresis was carried out for $1 \mathrm{~h}$ at 120 V. Gels were prepared with $0.5 \times$ Tris Borate EDTA-Buffer (TBE, Sigma-Aldrich) and Midori Green Advanced (Nippon Genetics). Gel bands were checked and documented under UVlight (UVP DocIt ${ }^{\circledR}$ ), and then with FastGene GelPic LED Box (Nippon Genetics). PCR products were purified using the Qiagen PCR Purification Kit and PCR Purification Kit by MachereyNagel. Both kits were used following the manufacturer's manual. Purified products were then transferred to a 96-well sequencing plate and mixed with sequencing primers. Sequencing was done by the Qiagen Sequencing Service.

All sequences of each strain were assembled automatically using the Geneious ${ }^{\mathrm{TM}}$ software package. Assembled contigs were checked manually for consistency of overlapping regions. Complete contigs were compared to existing entries in the NCBI data base using BLASTn-Search (Altschul, 1990). All contigs were then aligned using BioEdit (Hall, 1999) and SeaView (Gouy et al., 2010). A basis for alignment was the secondary structure of the 16S rRNA. Therefore, variable helices were folded using the mfold web server (Zuker, 2003) and conserved structure elements were taken as a basis for homolog regions. Reference sequences for phylogenetic analysis were taken from Shih et al. (2013) and several sequences directly from NCBI. They were selected for most comprehensive information, i.e., availability of an isolate, inclusion into a publication, sequence length and sequence quality.

16S rRNA gene phylogenies were calculated using Maximum Likelihood (ML) in MEGA 6 (Tamura et al., 2013), in RAxML (Stamatakis et al., 2005) and MrBayes for bayesian analysis. The MEGA 6 implemented Modeltest for best RNA/DNA model was run first, and the model with lowest $1 \mathrm{~nL}$ in the Akaike Criterion (AIC; Akaike, 1981) was chosen for Maximum Likelihood (ML) analysis. As an out-group, Gloeobacter violaceus PCC 7421 was used. The phylogeny clades were checked for reference strains and assigned to the clade names of Shih et al. (2013) and Komárek et al. (2014).

\section{RESULTS}

\section{Abundance and Composition}

Cyanobacteria of the orders Synechococcales and Oscillatoriales were always dominant in biomass and abundance, as shown in detail for the year 2006 for the Zingster Strom (Figure 2) and the 2006 yearly means for the whole lagoon system (Figure 3). Phytoplankton community showed nearly the same patterns and species composition over the last 20 years. Spring and summer biomasses differed from autumn blooms. In spring, Synechococcales and Bacillariophyceae dominated phytoplankton biomass. In autumn, cyanobacterial colonies and trichomes formed more than $80 \%$ of biomass. Synechococcales were present with high biomass and abundance the whole 


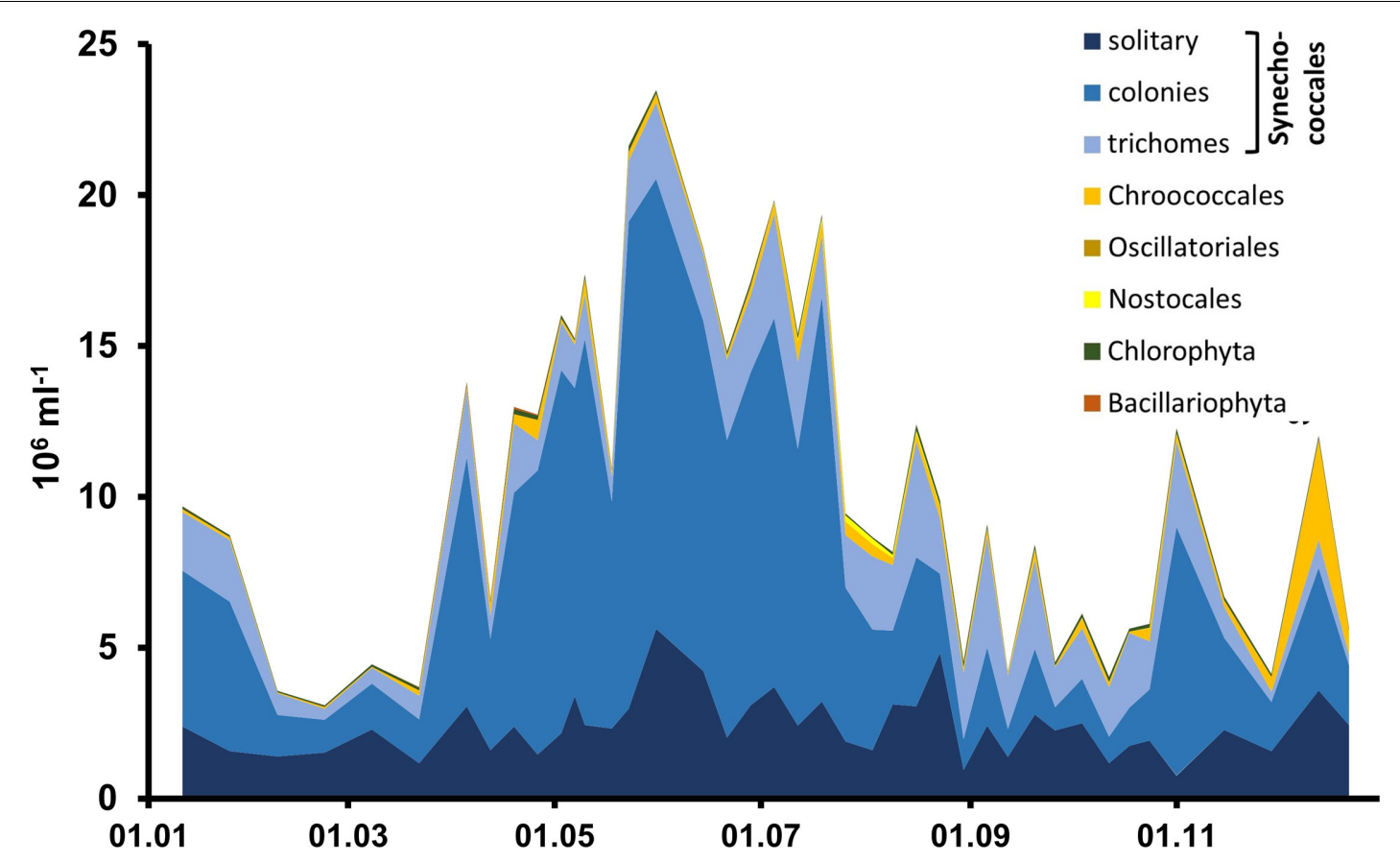

FIGURE 2 | Phytoplankton abundance based on counts with the light microscope, for the year 2006.

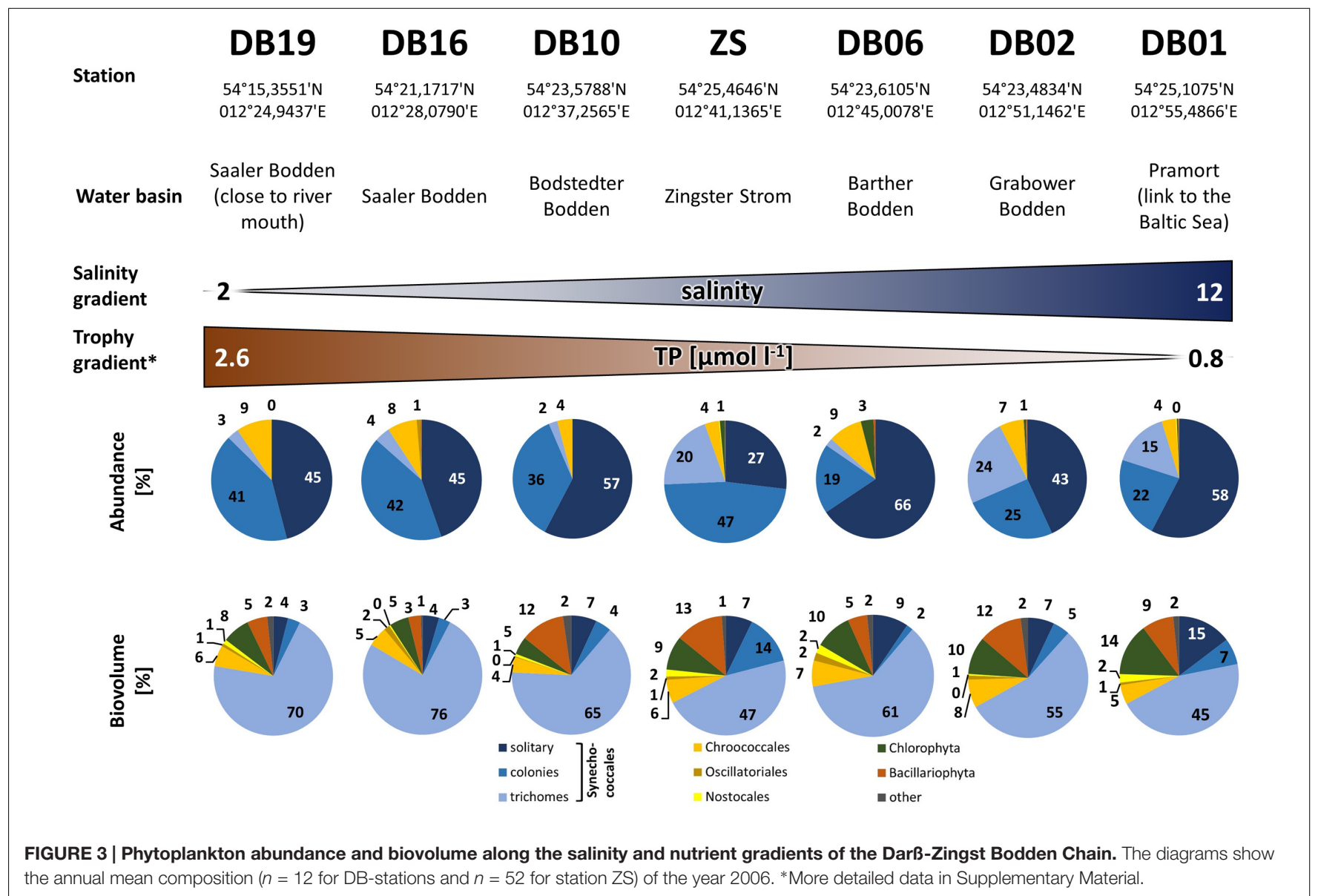


year (Figure 2). Chlorophyceae and Bacillariophyceae were also always present in phytoplankton, but mostly with low biomass. The dominance of certain species (morphotypes) varied from year to year, but cyanobacteria were always dominant. The dominance of cyanobacteria in abundance and biomass is found in the whole DZBC over the salinity and nutrient gradients that exist there (Figure 3).

The very small colony forming species (Synechococcales, Cyanobium) appeared with $2-21.10^{6}$ cells $\mathrm{ml}^{-1}$ (Figure 2) and comprised $47-93 \%$ of phytoplankton biomass throughout the year 2006. Cyanobacteria with heterocytes were present, but did not play a major role regarding phytoplankton biomass $(<2 \%)$. Toxic species such as Microcystis, Nodularia, Cylindrospermopsis and Anabaena played even minor role in the DZBC. They were only recognized in net samples for zooplankton (concentrated fivefold). All other species had an abundance of $<0.23 .10^{6}$ cells $\mathrm{ml}^{-1}$. Biomass and abundance of the Zingster Strom phytoplankton was also dominated by colony-forming picocyanobacteria during the sampling period in April and May 2013 (Figure 4). The trichomes of Planktolyngbya showed the highest biomass, while colonies and single cells of Synechococcales showed the highest abundance.

Most cyanobacteria of the DZBC had thick mucilage and formed colonies. The most abundant morphotypes belonged to the Aphanothece-complex, as described by Pankow (1990) for the genus. The cells were 1-2 $\mu \mathrm{m}$ long, rod-shaped, and straight (Aphanothece) or curved (Cyanodictyon). Colonies were compact (Aphanothece) or in loose formation (Cyanodictyon). Other cells were oval to spherical (Snowella, Merismopedia, Chroococcus, Aphanocapsa, Gloeothece) and formed regular (Merismopedia, Chroococcus) or irregular colonies (Snowella, Aphanocapsa) (Figure 5). Genus and species determination depended mostly on the colony shape. Cells were often too small to recognize features within the cells, if present. Only genera of Snowella, Woronichinia, Merismopedia and Microcystis were determined to species level at counting magnification, by their distinct morphotypes. Aphanothece, Aphanocapsa and Cyanodictyon were determined only at genus level, because their very small cells could hardly be measured to determine species. Non-colonyforming APP (autotrophic picoplankton) single cells were usually rod-shaped and were counted as Synechococcus sp.

The different cyanobacterial species are used to infer the ecological status of the water. One system for water classification is the Reynolds functional group system (Reynolds et al., 2002). In the Reynolds functional group system, this phytoplankton community fitted best into the K group. The habitat specification of this group is shallow and nutrient-rich, and typical representatives are Aphanothece and Aphanocapsa (Reynolds et al., 2002). The significance of this group's community structure was uncertain, except for a high $\mathrm{pH}$ tolerance (Reynolds et al., 2002).

\section{Morphological and Molecular Identification of Cyanobacterial Species}

The isolation of strains in a culture-dependent approach was a first attempt at more-precise identification and investigation of DZBC cyanobacteria. Fifty-three isolates were established. These isolates were determined morphologically as Limnothrix cf. obliqueacuminata, Limnothrix cf. rosea, Aphanothece cf. nidulans, Rhabdoderma cf. linearis, cf. Cyanodictyon planctonicum, cf. Aphanocapsa incerta, cf. Chroococcus vacuolatus, Synechocystis cf. diplocca (Figure 6), Cyanobium sp., Pseudanabaena sp., Merismopedia punctata and Cronbergia sp. (Figure 7). Morphology changed during culturing, from gelatinous aggregates to single cells (Figures 6, 7). Strain CZS $2 / 3$ (Merismopedia punctata) was the only isolate that was determined in situ. Therefore, this species determination is based on its original morphology and is the most reliable. The other isolates were named later, by their phylogenetic affiliation.

The isolates were taken for genetic analysis of the complete 16S rRNA gene, available under accession numbers KY379855KY379897. First, the sequences were checked with BLASTn. The best hit of BLASTn assigned isolates to the genera Synechococcus, Cyanobium, Pseudanabaena and Merismopedia. Some isolates

\section{Zingster Strom Phytoplankton 2013}
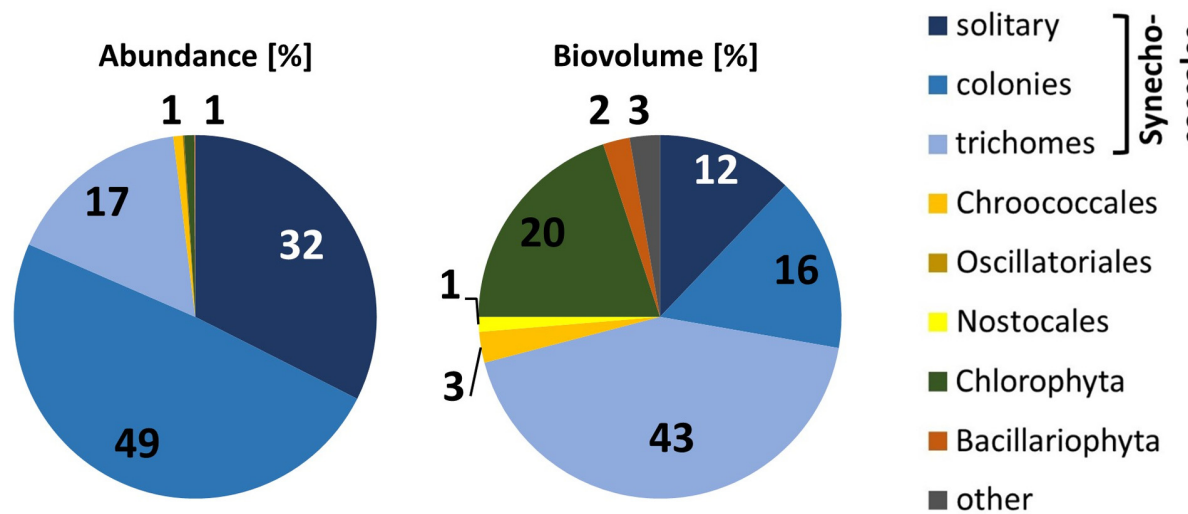

FIGURE 4 | Phytoplankton abundance and biovolume at the Zingster Strom, based on counts with the light microscope. Mean percentages for spring $2013(n=11)$. 


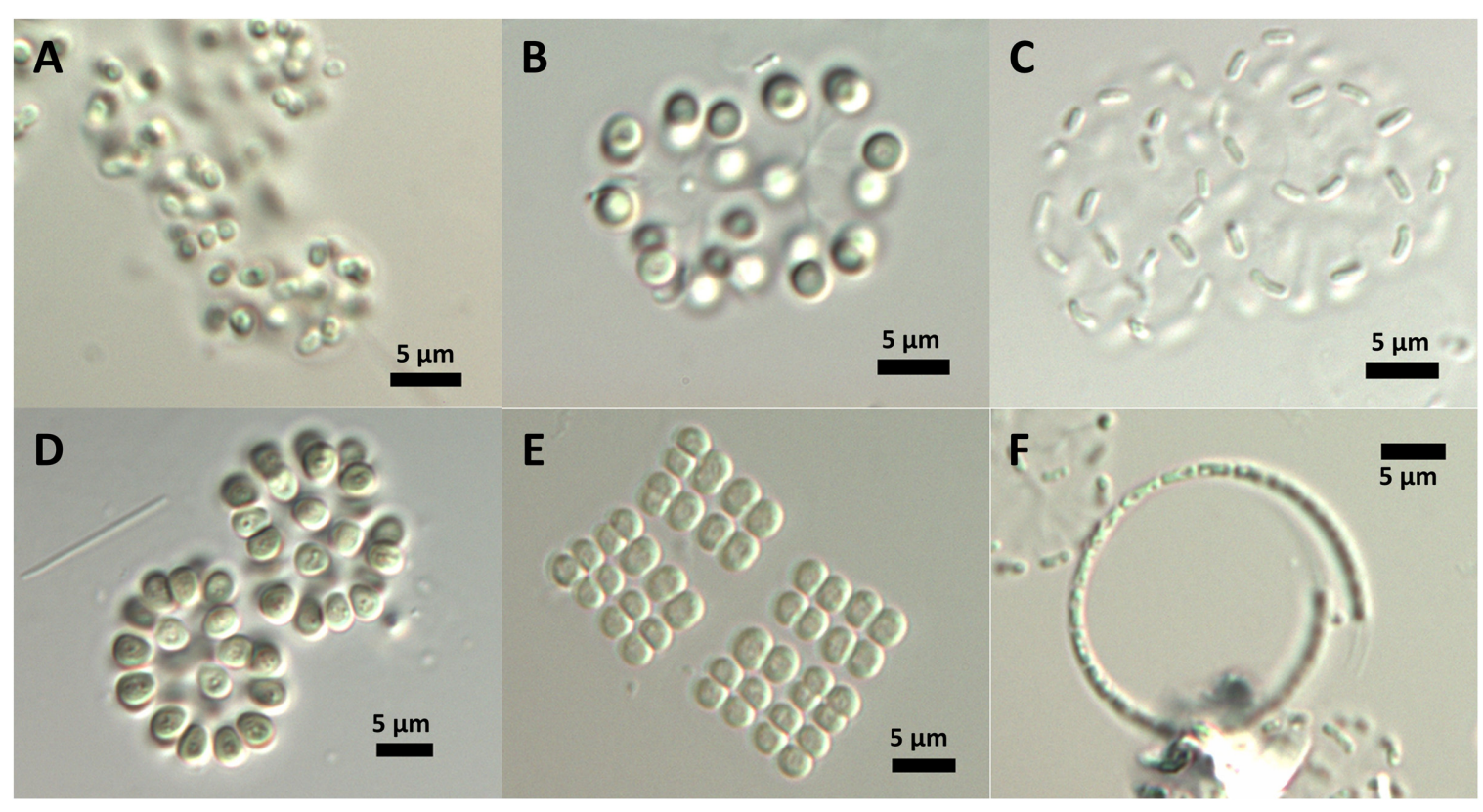

FIGURE 5 | In situ morphology of DZBC cyanobacteria species. (A) Gloeothece sp.; (B) Snowella sp.; (C) Cyanodictyon sp.; (D) Woronichinia sp.; (E) Merismopedia sp.; (F) Planktolyngbya contorta.

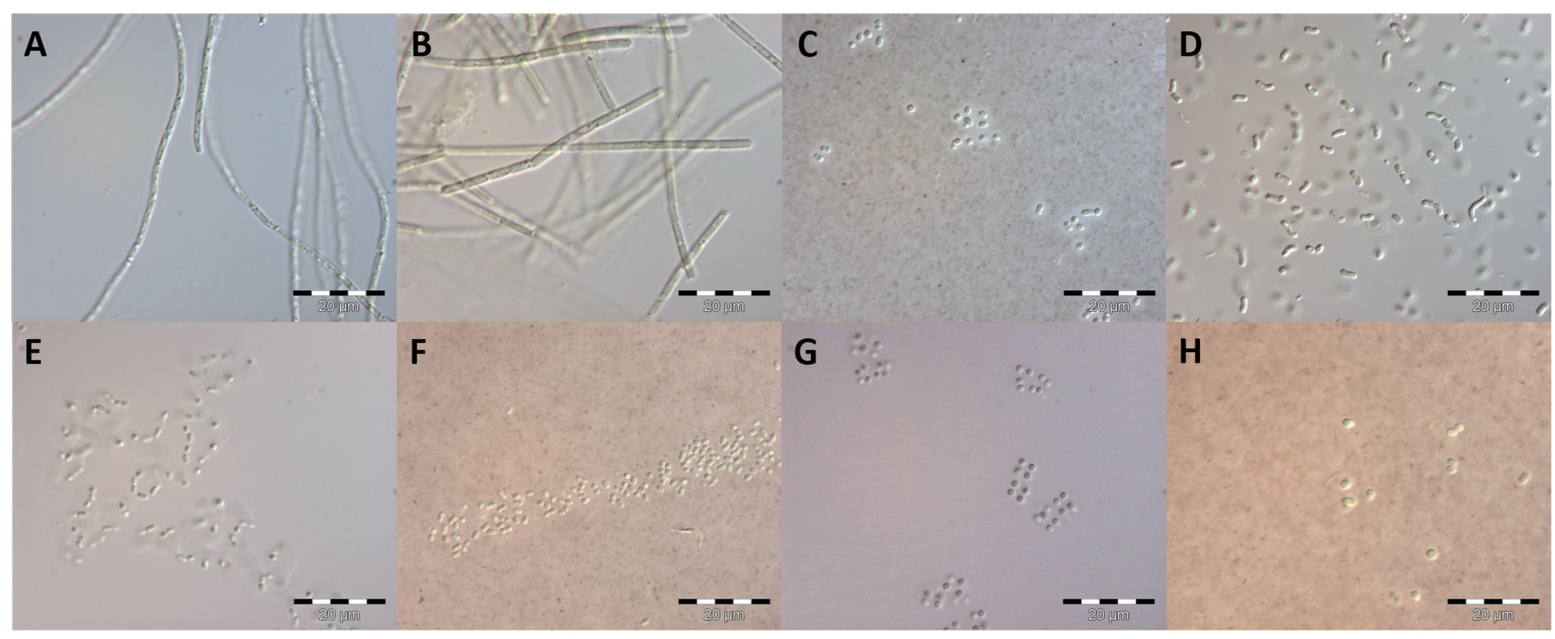

FIGURE 6 | Early culture stage (<4 weeks) of isolates as basis for morphological species determination. Species names refer to the morphological determination. Photographs (C,F,H) were stained with India Ink. (A) Limnothrix cf. obliqueacuminata; (B) Limnothrix cf. rosea; (C): Aphanothece cf. nidulans; (D): Rhabdoderma cf. linearis; (E): cf. Cyanodictyon planctonicum; (F): cf. Aphanocapsa incerta; (G): cf. Chroococcus vacuolatus; (H): Synechocystis cf. diplocca; scale bars: $20 \mu \mathrm{m}$.

could not be identified using BLASTn, because the nearest database sequence differed by more than $3 \%$ in nucleotides. These isolates belonged to the order Nostocales, after Komárek et al. (2014), which is clade B1 (Shih et al., 2013).The morphology also indicated Nostocales (clade B1) strains (Figure 7). According to the 16S rRNA gene phylogenies, all isolates belonged to the orders Nostocales (clade B1), Chroococcales (clade B2) or Synechococcales (clades $\mathrm{C} 1$ and F) (Figure 8). The isolates were all assigned to one of 5 clades, treated as genera
[ 1 genus of Nostocales, 1 genus of Chroococcales and 3 genera of Synechococcales (1 genus in clade C1, 1 genus in clade $\mathrm{C} 3$ and 1 genus in clade F)]. Most isolates were part of the clades of Cyanobium (44; clade C1) and Pseudanabaena (9; clade F) (Synechococcales). Two isolates belonged to Leptolyngbya (clade C3; Synechococcales) and one isolate was part of the Merismopedia-clade (clade B2; Chroococcales). Three isolates were assigned to the order Nostocales (clade B1). The phylogeny did not show a clear assignment to a clade within Nostocales, 


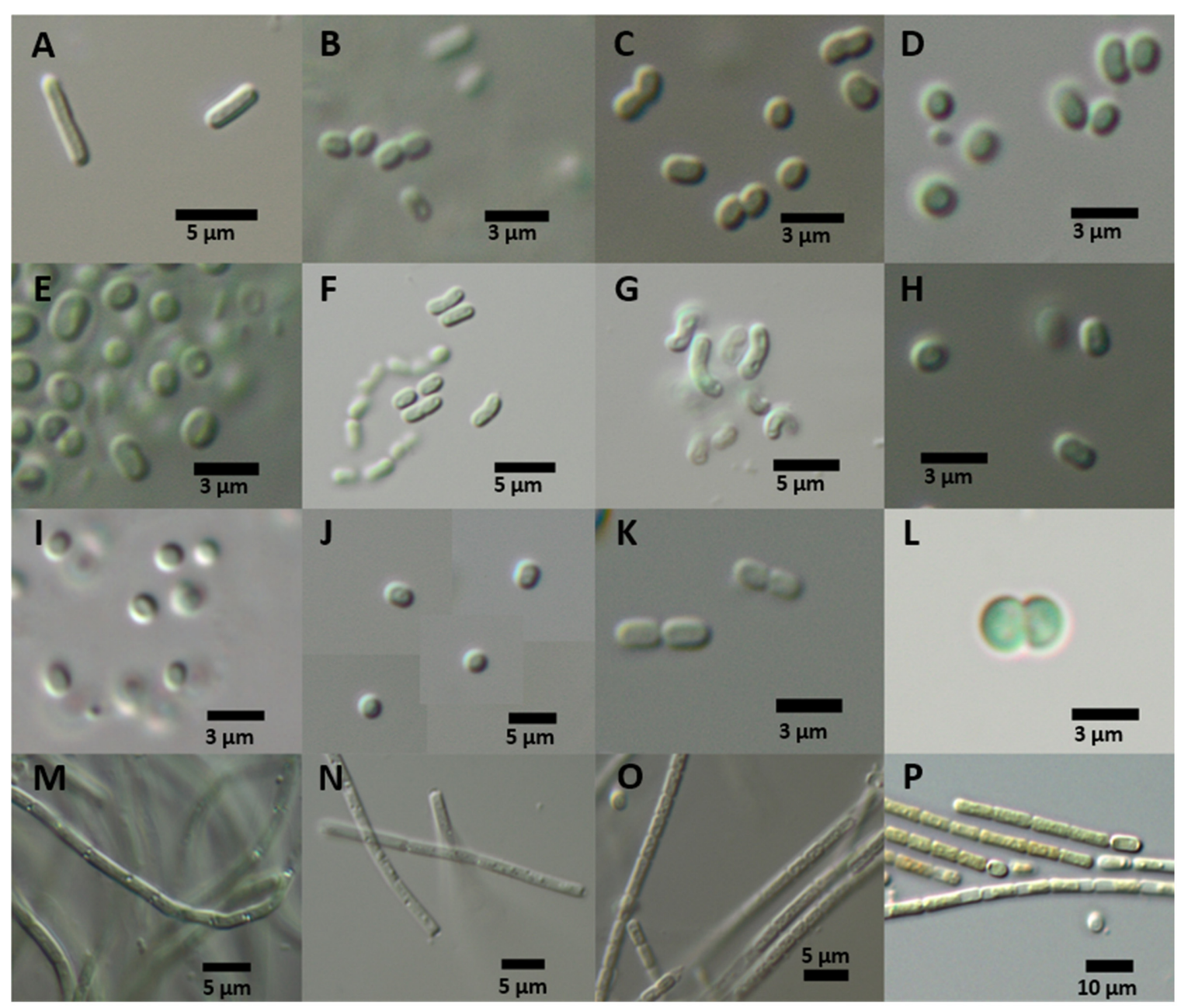

FIGURE 7 | Culture morphology of representative strains of phylogenetic clades after 1 year of culture. (A) Shows Synechococcus elongatus type strain and (B-P) show isolates of the DZBC. Generic names refer to the 16S rRNA gene phylogeny position. CZS-strains were isolated from the Zingster Strom. RK- and SB-strains originate from the Saaler Bodden (station DB16). (A) Synechococcus elongatus PCC 6301; (B-K) DZBC isolates of Cyanobium; (B) CZS 19G; (C) CZS 39E; (D) CZS 22C; (E) CZS 25K; (F) CZS 48K; (G) CZS 48M; (H) CZS 25G; (I) CZS 27J; (J) CZS 34G; (K) CZS 45I; (L) Merismopedia punctata strain CZS 2/3; (M) Leptolyngbya strain RK 2.3; (N) Pseudanabaena strain CZS 36B; (O) Pseudanabaena strain CZS 45C; (P) Nostocales strain SB 3.21 ; scale bars: $3 \mu \mathrm{m}$ (B-E,H,I,K,L); $5 \mu \mathrm{m}$ (A,F,G,J,M-O); $10 \mu \mathrm{m}$ (P).

and database searches showed the highest nucleotide congruency with only $97 \%$ sequence identity. The new clade is closely related to Cronbergia strain PCC6471 species. Morphology and molecular data showed contrasting results for the very small isolates. Morphologically, most isolates were determined as genera and species of the order Chroococcales. However, phylogenetically, they belong to the order Synechococcales (clade C1).

The heterocytous and non-heterocytous filamentous strains were mostly isolated from samples taken in autumn. Filamentous cyanobacteria occurred with the highest biomasses in that season (Schumann et al., 2001; Schoor et al., 2008). Only the very abundant non-heterocytous Planktolyngbya contorta could not be cultured. Most filaments did not have heterocytes and belonged to the orders Synechococcales (clade F) and Oscillatoriales (clade C3). Synechococcales filaments were morphologically assigned to the genera Pseudanabaena and Limnothrix. Other genera were determined as Leptolyngbya (clade C3) and Nostocales (clade B1) genus Cronbergia.

A second attempt was undertaken for a preliminary overview of the genotypes present. The clones of a full DZBC sample resulted in 52 sequences (KY327309-KY327360). Six genus names were found with BLAST first hits: Synechococcus, Cyanobium, Cyanobacterium, Aphanocapsa, Snowella and Limnococcus. The "Synechococcus" and "Cyanobacterium" clone sequences were quite similar (99\%) to Cyanobium PCC7001 within the clade C1/Synechococcales. Therefore, this result was partly in accordance with the in situ morphotypes. A phylogenetic analysis with selected sequences of the $608 \mathrm{bp}$ fragment of the $16 \mathrm{~S}$ rRNA gene showed the same results. Four genera were found based on the 16S rRNA gene phylogeny positions. Most clones belonged to the clades Snowella (22 


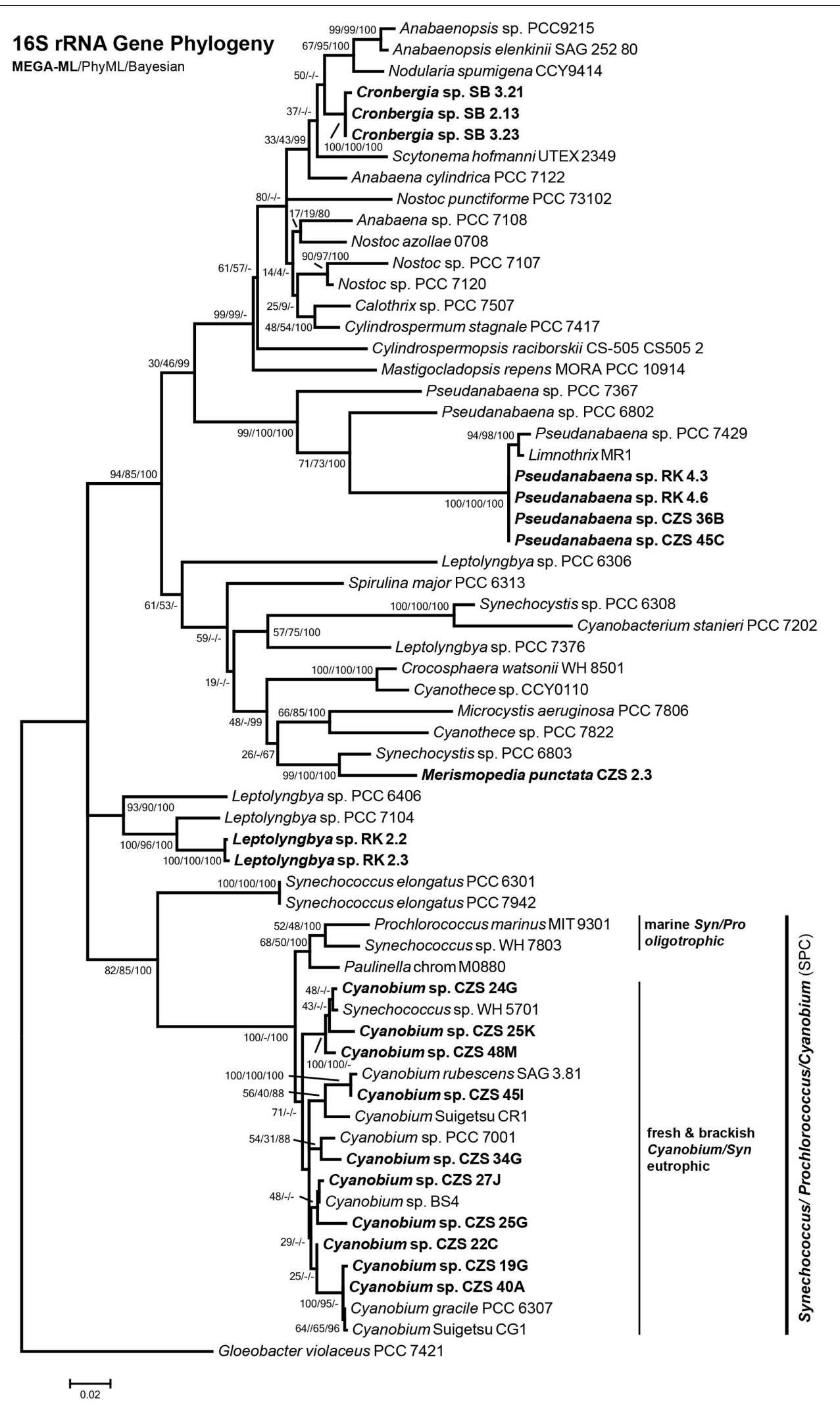

FIGURE 8 | Maximum Likelihood Phylogeny constructed with MEGA of 16S rRNA gene sequence (1356 bp). Node numbers show MEGA ML/PhyML/Bayesian statistical bootstrap support. In bold: DZBC isolates. Clade names sensu Shih et al. (2013) and Komárek et al. (2014). 
clones; clade B2/ Chroococcales) and Cyanobium (20 clones, clade $\mathrm{C} 1$, Synechococcales).

\section{DISCUSSION}

\section{Morphology In Situ}

Former investigations on the DZBC focused on the morphological determination of the cyanobacterial phytoplankton. Most abundant genera were Snowella, Planktolyngbya, Aphanothece, Aphanocapsa, Dolichospermum, Aphanizomenon, Coelosphaerium, Chroococcus, Merismopedia, Microcystis, Nodularia and Limnothrix (Pankow and Martens, 1973; Kell, 1973; Pankow, 1976; Nasev et al., 1978; Schumann et al., 2005). Pankow (1976) found about 40 different species per sampling station over the entire DZBC. The overlap of species between stations results in 61 cyanobacterial species in total for the entire DZBC. In later studies, Klinkenberg and Schumann (1995) found non-colony-forming APP picocyanobacteria, which were determined genetically as Synechococcus-like cyanobacteria (Geiß et al., 2004).

The small-celled species $(0.8-2 \mu \mathrm{m})$ occurred in very high cell numbers and also high biomass over the year. Other brackish waters with described Aphanothece-like species are the Curonian Lagoon and Vistula Lagoon, which are also located on the southern Baltic coast. However, filamentous, heterocytous cyanobacteria and Microcystis were most abundant in those lagoons (Pilkaitytë, 2007; Paldavičienè et al., 2009; Aleksandrov, 2010; Lange, 2011, 2014; Nawrocka and Kobos, 2011; Belykh et al., 2013; Olenina, 2013). The phytoplankton composition there has been analyzed mostly microscopically.
Brackish waters worldwide show diverse patterns, which were summarized for some lagoons by Lopes and Vasconcelos (2011). The dominance of picocyanobacterial species is reported for other lagoons, e.g., Patos Lagoon, Brazil or Florida Bay, United States (Phlips et al., 1999), Chesapeake Bay, United States (Wang and Chen, 2004; Chen et al., 2006) and Laguna Chascomús, Argentina (Iachetti and Llames, 2015) (Table 1). Similar phytoplankton communities are also found in freshwater lakes (e.g., Lake Santa Olalla, Spain (López-Archilla et al., 2004), Lake Baikal, Russia (Belykh et al., 2006), lakes in southern Sweden (Komárková-Legnerová and Cronberg, 1994), Guarapiranga Reservoir, Brazil (Santos et al., 2015), Vargem das Flores Reservoir, Brazil (Gomes et al., 2012), reservoirs along the Iguaçu River, Brazil (Silva et al., 2005) and in the Mount Cameroon region, Cameroon (Oben and Oben, 2006). Shallowness and a eutrophic state are common features of all these waters. Differences occur in colony-forming picocyanobacteria and APP assemblages, and in the temporal development. Most lagoons and lakes show enormous seasonal changes in the phytoplankton community. The DZBC has colony-forming picocyanobacteria and APP in high cell numbers and with high biovolume year-round, which makes it a special and unique system.

\section{Features and Determination}

The determination of picocyanobacteria is especially difficult due to their size and lack of microscopically identifiable features. The occurrence as single cells (APP) or a colony is the first distinctive feature. Single cells without a mucilage are determined as Synechococcus-like (rod-shaped) or Synechocystislike (coccoid). Colony-forming genera are determined by the

TABLE 1 | Overview of articles on lagoons worldwide, with picocyanobacteria occurrence and dominance.

\begin{tabular}{|c|c|c|c|c|c|}
\hline Lagoon $^{a}$ & Properties & Genera & Names according to & Method & Reference \\
\hline Çaygören Reservoir & & Aphanocapsa, Aphanothece & $\begin{array}{l}\text { Komárek and Anagnostidis, } \\
\text { 2005; names updated after } \\
\text { AlgaeBase }\end{array}$ & Light microscopy & $\begin{array}{l}\text { Çelık and Sevındık, } \\
2015\end{array}$ \\
\hline $\begin{array}{l}\text { Vistula Lagoon } \\
\text { (POL) }\end{array}$ & $\begin{array}{l}\text { shallow brackish } \\
\text { eutrophic }\end{array}$ & $\begin{array}{l}\text { Aphanocapsa, Aphanothece, } \\
\text { Cyanodictyon, Merismopedia, } \\
\text { Snowella, Woronichinia }\end{array}$ & Functional groups & Light microscopy, Lugol & $\begin{array}{l}\text { Nawrocka and } \\
\text { Kobos, } 2011\end{array}$ \\
\hline $\begin{array}{l}\text { Curonian Lagoon } \\
\text { (LIT) }\end{array}$ & shallow brackish & some colonies & Not provided & Light microscopy, Lugol & Pilkaitytë, 2007 \\
\hline Venice Lagoon (ITA) & $\begin{array}{l}\text { Near marine, } \\
\text { shallow }\end{array}$ & $\begin{array}{l}\text { Coelosphaerium kutzingianum, C. } \\
\text { minutissimum, Aphanothece, } \\
\text { Synechococcus }\end{array}$ & Not provided & $\begin{array}{l}\text { Epifluorescence } \\
\text { microscopy }\end{array}$ & Sorokin et al., 2004 \\
\hline $\begin{array}{l}\text { Laguna de Tres } \\
\text { Palos (MEX) }\end{array}$ & $\begin{array}{l}\text { Oligohaline, } \\
\text { hypereutrophic, } \\
\text { shallow }\end{array}$ & $\begin{array}{l}\text { Aphanocapsa delicatissima, } \\
\text { Merismopedia punctata, Chroococcus } \\
\text { dispersus var. minor, Raphidiopsis } \\
\text { curvata, Pseudanabaena limnetica }\end{array}$ & $\begin{array}{l}\text { Caljon, 1983; Moreno-Ruíz, } \\
\text { 2000, 2005; Moreno, } 2003\end{array}$ & Light microscopy, Lugol & $\begin{array}{l}\text { de la Lanza Espino } \\
\text { et al., } 2008\end{array}$ \\
\hline $\begin{array}{l}\text { Patos Lagoon } \\
\text { (BRA) }\end{array}$ & Shallow brackish & $\begin{array}{l}\text { Aphanocapsa nubilum, Planktolyngbya } \\
\text { limnetica, Cyanodictyon imperfectum }\end{array}$ & Not provided & Light microscopy & Torgan et al., 2006 \\
\hline $\begin{array}{l}\text { Lake Santa Olalla } \\
\text { (SPA) }\end{array}$ & $\begin{array}{l}\text { Shallow } \\
\text { hypertrophic }\end{array}$ & $\begin{array}{l}\text { Aphanothece, Chroococcus, } \\
\text { Nostocales filaments }\end{array}$ & $\begin{array}{l}\text { Anagnostidis and Komárek, } \\
\text { 1985; Waterbury, } 1991\end{array}$ & $\begin{array}{l}\text { Epifluorescence } \\
\text { microscopy, } \\
\text { Formaldehyde }\end{array}$ & $\begin{array}{l}\text { López-Archilla } \\
\text { et al., } 2004\end{array}$ \\
\hline $\begin{array}{l}\text { Laguna } \\
\text { Chascomús (ARG) }\end{array}$ & Fresh water shallow & $\begin{array}{l}\text { Aphanocapsa, Raphidiopsis, } \\
\text { Planktolyngbya }\end{array}$ & Not provided & Light microscopy, Lugol & $\begin{array}{l}\text { lachetti and } \\
\text { Llames, } 2015\end{array}$ \\
\hline
\end{tabular}

a Abbreviations for countries: ARG, Argentina; BRA, Brazil; ITA, Italy; LIT, Lithuania; MEX, Mexico; POL, Poland; SPA, Spain. 
colony shape, presence or absence of a common mucilage, cell shape and size, or by special features such as gelatinous stalks. These are variable features, which may be absent or changed by environmental factors. However, there were some stable morphological features in situ which were used for determination of genera, e.g., gelatinous stalks of Snowella, general cell shape (rod-shaped or spherical) or aggregation in colonies (Figure 2) (Komárek and Anagnostidis, 1999, 2005; Komárek et al., 2014). According to Jasser and Callieri (2017b), the standard operation protocol is based on epi-fluorescence enumeration of picocyanobacteria. The determination of species by epifluorescence is not possible; instead, picocyanobacteria are devided by their main pigments [phycoerythrin (PE) or phycocyanine (PC) type].

The order Chroococcales (clade B2; e.g., the morphospecies Aphanothece, Snowella, Woronichinia, Merismopedia) shows a greater variety of stable features compared to the pico-size $(0.2-2 \mu \mathrm{m})$ Synechococcales (clade C1), which consists mainly of very small, solitary, rod-shaped cells (Komárek and Anagnostidis, 1999; Komárek et al., 2014). The most abundant morphospecies was Aphanothece. No cultures could be established from this genus, perhaps because this genus was not present in the samples. Isolation of Snowella species was also not successful. Due to their distinctive characteristics, as there are presence of thin gelatinous stalks, radial and loose position of cells, the determination of Snowella by morphology seems to be correct and was verified by molecular genetic investigations (Rajaniemi-Wacklin et al., 2006). The identification of isolates that have been cultured for months or years can be difficult, due to the morphological changes and misleading molecular database information. Erroneous identifications in databases are caused mainly by misidentification of strains (Komárek and Anagnostidis, 1989) before sequencing and depositing the data under the wrong name. Further, specific literature on determinations is missing for marine, brackish and terrestrial habitats. Most species are determined in fixed samples, using the Süßwasserflora by Komárek and Anagnostidis (1989). The authors of these keys covered a wide range of cyanobacteria, but the focus in the Süßwasserflora is on freshwater habitats. Pankow (1990) described the phytoplankton of the brackish Baltic Sea region, and developed a key for determination, including drawings and micrographs, although only on morphological properties.

\section{Applied Morphological Aspects}

Different researchers counted the APP, if it was recognized at all, in different ways. Some counted all pico-cyanobacteria as APP or Synechococcus-like (see Callieri, 2007 and references therein). We counted the free-living single cells as Synechococcus spp. The cells were rod-shaped and not part of a colony. Counting them as Synechococcus sp. was a pragmatic approach, because of the very few morphological features. Other investigations also used this categorization for analyses, e.g., in the flow cytometer (Schapira et al., 2010). The size, form, and absence of visible mucilage supported the morphological determination as Synechococcus sp. (Komárek and Anagnostidis, 1999). However, these cells could be fragments of colonies, when the colonies consisted of rod-shaped cells. Colonies with rod-shaped cells, such as Aphanothece, were very abundant in the DZBC (Figure 2), and there was no morphological feature indicating a separation between colony fragments and obligate solitary cells. Differentiation can only be assessed by molecular methods, to detect cryptic diversity. The molecular phylogeny cannot be reconstructed from the morphology (Palinska et al., 1996), especially for genera with very small cells. This leads to problems in determination up to order levels. The result is uncertainty about the ecophysiology and health risk potentials. Further, it leads to difficulties in the interpretation of monitoring results, because genera are set as indicator taxa (Reynolds et al., 2002; Padisák et al., 2009).

The classification in the Reynolds system (Reynolds et al., 2002) gave ambiguous results for the DZBC. The dominance of Aphanothece and Aphanocapsa-like morphospecies fits the shallow, turbid, nutrient-rich water of the DZBC. The result would be group K, according to Reynolds et al. (2002). A high $\mathrm{pH}$ tolerance was mentioned for this group as a special feature. Growth under light limitation and with changing salinities may be added as special features for the DZBC community. Group S1 (Reynolds et al., 2002) also matches the conditions found at the DZBC. The highly turbid, very low Secchi-depth waters (down to $20 \mathrm{~cm}$ ) in the DZBC and the presence of Pseudanabaena and Limnothrix morphospecies concord with this group. Previous investigations in the DZBC found high abundances of Synechococcus. However, group Z can be excluded because it focuses mainly on oligotrophic marine waters. This classification into functional groups is based on microscopy counting data, and may serve as a rough estimation of the population features. These data are used by environmental agencies and are part of the Water Framework Directive (2000).

\section{Molecular Data}

The combination of morphology and molecular data proved to be useful for the identification of the DZBC phytoplankton community. Morphological and molecular analyses in situ and in vitro gave partly contrasting results. These differences can be explained by culturing biases, misleading determination features, ambiguous database entries, and the plasticity of Cyanobium as shown by Jezberová and Komárková (2007a,b) and Huber et al. (2017). The focus was on the most conserved and reliable feature, the 16S rRNA gene. The 16S rRNA gene is used mostly to identify prokaryotes (Oren, 2011; Palinska and Surosz, 2014). The 16S rRNA gene is a conserved marker that reliably reveals the major phylogenetic lineages down to genus level (Woese, 1987). Phylogenies of 16S rRNA gene sequences showed that our isolates and many clone sequences were part of the Cyanobium clade. The affiliation to Cyanobium concords to the non-marine habitat conditions (Jasser and Callieri, 2017a).

The sequence data for the $16 \mathrm{~S}$ rRNA gene clone support the occurrence of Snowella in situ. In contrast, no sequences of Aphanothece were found, although members of this genus were highly abundant according to morphological data. Many 16S rRNA gene sequences from the culture-independent cloning, as well as from the culture-dependent approach, instead belonged to the genus Cyanobium. The cell shape of Cyanobium is similar to that of Aphanothece. Major differences between 
TABLE 2 | Occurrence of Cyanobium in brackish and fresh-water habitats, as inferred by genetic determinations.

\begin{tabular}{|c|c|c|}
\hline Water system ${ }^{a}$ & Reference & Method \\
\hline Baltic Sea & $\begin{array}{l}\text { Ernst et al., 2003; Haverkamp et al., } \\
\text { 2009; Celepli et al., } 2017\end{array}$ & Culture isolation, $16 \mathrm{~S}$ rRNA, metagenomes \\
\hline $\begin{array}{l}\text { Lake Constance (GER), Lake Maggiore (ITA), } \\
\text { Lake Biwa (JAP) }\end{array}$ & Ernst et al., 2003 & Culture isolation, $16 \mathrm{~S}$ rRNA \\
\hline Reservoirs Nová Říše, Římov, Vír (CZE) & Jezberová and Komárková, 2007b & Culture isolation, $16 \mathrm{~S}$ rRNA \\
\hline $\begin{array}{l}\text { Lake Balaton (HU), Lake Zurich (SWI), Lake } \\
\text { Constance (GER) }\end{array}$ & Ernst et al., 1999 & Culture isolation, $16 \mathrm{~S}$ rRNA \\
\hline Albufera Lagoon (SPA) & Ghai et al., 2012 & Metagenomes \\
\hline Chesapeake Bay (USA) & Xu et al., 2015 & Culture isolation, $16 \mathrm{~S}$ rRNA \\
\hline Coorong Lagoon (AUS) & Schapira et al., 2010 & Flow cytometry \\
\hline
\end{tabular}

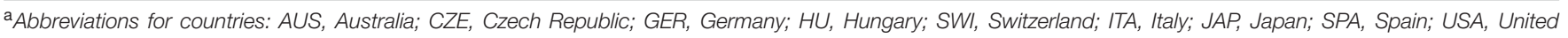
States of America

these two genera are the formation of colonies and the position of the thylakoids. Aphanothece forms colonies and has irregular thylakoids. Cyanobium consists of solitary cells and has parietal thylakoids (Komárek et al., 2014). The position of the thylakoids cannot be determined with light microscopy, so the only remaining easily visible difference is the formation of colonies. For example, Jezberová and Komárková (2007a,b) and Huber et al. (2017) demonstrated the variability of this feature under different culture conditions. The formation of colonies depended on the presence of a grazer. Jezberová and Komárková (2007a,b) and Huber et al. (2017) conducted experiments using strains of the Synechococcus-Prochlorococcus-Cyanobium clade (SPC-clade), which were phylogenetically different Cyanobium lineages. These strains were determined as Anathece by Jezberová and Komárková (2007a), because of their ability to form colonies. The separation of Anathece from Cyanobium was based on morphology (Komárek et al., 2011), whereas there is no evidence for this in the phylogeny. Moreover, Huber et al. (2017) demonstrated the variability of this feature. The strains that we isolated belonged to the same Cyanobium lineages, but consisted of solitary cells under our grazer-free culture conditions. Grazers were present in situ (Heerkloss et al., 2006), so our isolates may form colonies under the stimulus of grazing, as shown for other morphological changes in green algae (Lampert et al., 1994). The small number of different genera in the DZBC is also reflected in a $16 \mathrm{~S}$ rRNA gene DGGE fingerprint that resulted in only four bands (Schlie, 2009).

The 16S rRNA gene phylogeny (Figure 8) shows different lineages of the APP and colony-forming isolates. The clades consist of selected representatives of DZBC strains and closely related reference strains. It is possible that some of the DZBC isolates form a distinct clade (e.g., CZS 22C). Much more likely is that this gap will be filled by transitional strains. A bias in this respect is caused by the selection of reference strains included in this study. Only strains with a complete $16 \mathrm{~S}$ rRNA gene sequence were included in the preliminary and the final analyses. Therefore, the well-studied Chesapeake Bay strains ( $\mathrm{Xu}$ et al., 2015) and others were not included. The lack of comparable data sets is a major problem for genetic analyses. The same marker genes may be used (e.g., the ribosomal operon), but the sequence length (e.g., whole or partial 16S rRNA gene) and the exact marker position (e.g., 16S rRNA or ITS or 23S rRNA genes) vary in many cases. The number of known genome sequences has increased in recent years (e.g., Scanlan et al., 2009; Shih et al., 2013) and may eventually result in more comparable data sets.

\section{Conclusion and Importance for Applied Questions}

Our investigations lead to two consequences: (i) Counted single cells are very likely genetically the same as the colonies, and (ii) the colonies found were members of Cyanobium (order Synechococcales/clade C1) and not Aphanothece (Chroococcales, clade B2). This hypothesis is supported by the fact that both our approaches showed no sequences of Aphanothece, even though this genus was highly abundant as determined morphologically. A sequence signal by the Aphanothece-like species (if present) could have been expected, because of the high cell numbers and the general cyanobacterial primers used.

The morphological features of APP and colony-forming picocyanobacteria are few, and depend strongly on the environmental conditions. Therefore, the determination of genera is difficult and misidentification often occurs. The genus Aphanothece seemed to be abundant in many eutrophic lagoons and lakes worldwide, as investigated morphologically. Molecular genetic investigations in waters with more or less similar environmental conditions gave different results. Cyanobium or Synechococcus sequences were often found, but not sequences of Aphanothece (Table 2). Phylogenetic analyses showed that many sequences determined as Synechococcus are actually Cyanobium (e.g., Synechococcus sp. WH5701). Cyanobium may be the most important pico-cyanobacterial (APP and colonyforming) contributor in eutrophic fresh and brackish waters worldwide.

Application of molecular genetic methods is necessary to identify genera and to validate microscopy data. The small size and variable morphology of pico-cyanobacteria make determination of members of this group through light microscopy uncertain and sometimes misleading. Linking of genetic species determination to morphology-based counting data should also be considered for the Reynolds functional-group 
classification. For example, addition of Cyanobium to the typical representatives of the K-group would allow molecular genetic data to be used as well. Calibration for such a revision could be done at stations where both morphospecies and molecular data are available. This would make research data more useful for environmental agencies, and provide a basis for the application of basic research data to monitoring. Problems still persist, because the nomenclature of cyanobacteria is not yet unified, even within the scientific community. They are either treated under the rules of Prokaryotes or under the former Botanical Nomenclature Code (Oren, 2011), but steps for unification are made (Oren and Garrity, 2014).

The dominant cyanobacteria species of the DZBC belong to the genus Cyanobium. It is very likely that in other lagoons where Aphanothece or Synechococcus have been reported in high numbers, Cyanobium is also the dominant phytoplankton genus, a suspicion that must be verified by molecular data. Therefore, the present view of the morphology of Cyanobium must be revised regarding colony and mucilage formation, as has begun with the work of Huber et al. (2017). The in situ morphology must be linked to the genetic marker, either by single-colony analysis or by fluorescence in situ hybridization (FisH) techniques. Comparison of Cyanobium sequences via qPCR against general cyanobacterial primers is another possible way to check the abundance of these picocyanobacteria in environmental samples. The application of next-generation $16 \mathrm{~S}$ amplicon sequencing may also provide hints of the genetic diversity present in environmental samples, avoiding biases from culturing. The limitations of these methods are determined by the primer specificity and PCR biases. Nevertheless, they will give a deeper insight into the in situ genetic diversity than can be obtained with culture-based approaches.

\section{REFERENCES}

Akaike, H. (1981). Likelihood of a model and information criteria. J. Econ. 16, 3-14. doi: 10.1016/0304-4076(81)90071-3

Aleksandrov, S. V. (2010). Biological production and eutrophication of Baltic Sea estuarine ecosystems: the Curonian and Vistula Lagoons. Mar. Pollut. Bull. 61, 205-210. doi: 10.1016/j.marpolbul.2010.02.015

Altschul, S. F. (1990). Basic local alignment search tool. J. Mol. Biol. 215, 403-410. doi: 10.1016/S0022-2836(05)80360-2

Anagnostidis, K., and Komárek, J. (1985). Modern approach to the classification system of cyanophytes. Arch. Hydrobiol. Suppl. 71, 291-302.

Belykh, O. I., Dmitrieva, O. A., Gladkikh, A. S., and Sorokovikova, E. G. (2013). Identification of toxigenic cyanobacteria of the genus Microcystis in the Curonian Lagoon (Baltic Sea). Oceanology 53, 71-79. doi: 10.1134/ S0001437013010025

Belykh, O. I., Ekaterina, G., Sorokovikova, T., Saphonova, A., and Tikhonova, I. V. (2006). Autotrophic picoplankton of Lake Baikal: composition, abundance and structure. Hydrobiologia 568(Suppl. 1), 9-17. doi: 10.1007/s10750-006-0340-8

Bergmann, B., Gallon, J. R., Rai, A. N., and Stal, L. J. (1997). N2 Fixation by nonheterocystous cyanobacteria. FEMS Microbiol. Rev. 19, 139-185. doi: 10.1016/ S0168-6445(96)00028-9

Caljon, A. (1983). Brackish-Water Phytoplankton of the Flemish Lowland: Developments in Hydrobiology, Vol. 18. Dordrecht: Springer, 1-272.

Callieri, C. (2007). Picophytoplankton in freshwater ecosystems: the importance of small-sized phototrophs. Freshw. Rev. 1, 1-28.

\section{AUTHOR CONTRIBUTIONS}

MA: Introduction, Materials and Methods, Results, Discussion, except for the following contributions by the other authors. RS: Section Cell Counts (Figures 2-4), micrographs (Figure 5), section Applied Aspects in Discussion as well as conceptual basis. TP: Basis for alignment of sequences, conceptual work on aspects of molecular biology and molecular taxonomy.

\section{FUNDING}

This work was funded by a scholarship from the Ministry of Education, Science and Culture of Mecklenburg-Vorpommern, Germany.

\section{ACKNOWLEDGMENTS}

We thank Tatyana Darienko for her help with culturing and morphological determination, Ingrid Sassenhagen and Carolin Schlie for isolating and determining several strains in the years 2009 and 2010, and Anja Hansen for counting samples from the DZBC. We also thank the Biological Station Zingst staff members Rita Wulff and Volker Reiff for their support in sampling and nutrient analyses.

\section{SUPPLEMENTARY MATERIAL}

The Supplementary Material for this article can be found online at: http://journal.frontiersin.org/article/10.3389/fmicb. 2017.00923/full\#supplementary-material

Caroppo, C. (2015). Ecology and biodiversity of picoplanktonic cyanobacteria in coastal and brackish environments. Biodivers. Conserv. 24, 949-971. doi: 10.1007/s10531-015-0891-y

Celepli, N., Sundh, J., Ekman, M., Dupont, C. L., Yooseph, S., Bergman, B., et al. (2017). Meta-omic analyses of Baltic Sea cyanobacteria: diversity, community structure and salt acclimation. Environ. Microbiol. 19, 673-686. doi: 10.1111/ 1462-2920.13592

Çelık, K., and Sevındık, T. (2015). The phytoplankton functional group concept provides a reliable basis for ecological status estimation in the Çaygören Reservoir (Turkey). Turk. J. Bot. 39, 588-598. doi: 10.3906/bot-1402-69

Chen, F., Wang, K., Kan, J., Suzuki, M., and Wommack, E. (2006). Diverse and unique picocyanobacteria in Chesapeake Bay, revealed by 16S-23S rRNA internal transcribed spacer sequences. Appl. Environ. Microbiol. 72, 2239-2243. doi: 10.1128/AEM.72.3.2239-2243.2006

Chisholm, S. W., Frankel, S. L., Goericke, R., Olson, R. J., Palenik, B., Waterbury, J. B., et al. (1992). Prochlorococcus marinus nov. gen. nov. sp.: an oxyphototrophic marine prokaryote containing divinyl chlorophyll $a$ and $b$. Arch. Microbiol. 157, 297-300. doi: 10.1007/BF00245165

de la Lanza Espino, G., Alcocer Durand, J., Moreno Ruiz, J. L., and Hernández Pulido, S. (2008). Análisis químico-biológico para determinar el estatus trófico de la Laguna de Tres Palos, Guerrero, México. Hidrobiológica 18, 21-30.

Ernst, A., Becker, S., Hennes, K., and Postius, C. (1999). "Is there a succession in the autotrophic picoplankton of temperate zone lakes?," in Proceedings of the 8th International Symposium on Microbial Ecology, eds C. R. Bell, M. Brylinsky, and P. Johnson-Green (Halifax, NS: Atlantic Canada Society for Microbial Ecology). 
Ernst, A., Becker, S., Wollenzien, U. I. A., and Postius, C. (2003). Ecosystemdependent adaptive radiations of picocyanobacteria inferred from 16S rRNA and ITS-1 sequence analysis. Microbiology 149, 217-228. doi: 10.1099/mic.0. 25475-0

Geiß, U., Selig, U., Schumann, R., Steinbruch, R., Bastrop, R., Hagemann, M., et al. (2004). Investigations on cyanobacterial diversity in a shallow estuary (Southern Baltic Sea) including genes relevant to salinity resistance and iron starvation acclimation. Environ. Microbiol. 6, 377-387. doi: 10.1111/j.14622920.2004.00569.x

Ghai, R., Mella Hernandez, C., Picazo, A., Megumi Mizuno, C., Ininbergs, K., Díez, B., et al. (2012). Metagenomes of Mediterranean coastal lagoons. Sci. Rep. 2:490. doi: 10.1038/srep00490

Gomes, L. N. L., Oliveira, S. M., Giani, A., and von Sperling, E. (2012). Association between biotic and abiotic parameters and the occurrence of cyanobacteria in a Brazilian reservoir. Environ. Monit. Assess. 184, 4635-4645. doi: 10.1007/ s10661-011-2291-4

Gouy, M., Guindon, S., and Gascuel, O. (2010). SeaView version 4: a multiplatform graphical user interface for sequence alignment and phylogenetic tree building. Mol. Biol. Evol. 27, 221-224. doi: 10.1093/molbev/msp259

Guiry, M. D., and Guiry, G. M. (2016). AlgaeBase. World-wide Electronic Publication, National University of Ireland, Galway. Available at: http://www. algaebase.org

Hall, T. A. (1999). BioEdit: a user-friendly biological sequence alignment editor and analysis program for Windows 95/98/NT. Nucleic Acids Symp. Ser. 41, 95-98.

Haverkamp, T. H. A., Schouten, D., Doeleman, M., Wollenzien, U., Huisman, J., and Stal, L. J. (2009). Colorful microdiversity of Synechococcus strains (picocyanobacteria) isolated from the Baltic Sea. ISME J. 3, 397-408. doi: 10.1038/ismej.2008.118

Heerkloss, R., Feike, M., and Busch, A. (2006). Zooplankton monitoring of the Darß-Zingst lagoon - long-term changes and inter-annual variability. Rostock. Meeresbiolog. Beitr. 16, 93-113.

HELCOM (1988). Guidelines for the Baltic monitoring programme for the third stage. Part D. Biological determinands. Balt. Sea Environ. Proc. 27D:161.

Huber, P., Diovisalvi, N., Ferraro, M., Metz, S., Lagomarsino, L., Llames, M. E., et al. (2017). Phenotypic plasticity in freshwater picocyanobacteria. Environ. Microbiol. 19, 1120-1133. doi: 10.1111/1462-2920.13638

Iachetti, C. M., and Llames, M. E. (2015). Light limitation helps stabilize the phytoplankton assemblage steady-state in a temperate and highly turbid, hypertrophic shallow lake (Laguna Chascomús, Argentina). Hydrobiologia 752, 33-46. doi: 10.1007/s10750-014-2045-8

Jasser, I., and Callieri, C. (2017a). "Picocyanobacteria: the smallest cell-size cyanobacteria," in Handbook of Cyanobacterial Monitoring and Cyanotoxin Analysis, eds J. Meriluoto, L. Spoof, and G. A. Codd (Chichester: John Wiley \& Sons), 19-27. doi: 10.1002/9781119068761.ch3

Jasser, I., and Callieri, C. (2017b). "Standard operating protocol: analysis of picocyanobacteria abundance in epifluorescnece microscopy," in Handbook of Cyanobacterial Monitoring and Cyanotoxin Analysis, eds J. Meriluoto, L. Spoof, and G. A. Codd (Chichester: John Wiley \& Sons), 39-342.

Jezberová, J., and Komárková, J. (2007a). Morphological transformation in a freshwater Cyanobium sp. induced by grazers. Environ. Microbiol. 9, 1858-1861.

Jezberová, J., and Komárková, J. (2007b). Morphometry and growth of three Synechococcus-like picoplanktic cyanobacteria at different culture conditions. Hydrobiologia 578, 17-27. doi: 10.1007/s10750-006-0429-0

Kell, V. (1973). Kurzzeitige Veränderungen des Phytoplanktonvolumens Ende Mai/ Anfang Juni 1972 in den Darßer Boddengewässern (südliche Ostsee). Wiss. Z. Univ. Rostock Math. Naturwiss. Reihe 22, 1105-1111.

Klinkenberg, G., and Schumann, R. (1995). Abundance changes of autotrophic and heterotrophic picoplankton in the Zingster Strom, a shallow, tideless estuary south of the Darß-Zingst Peninsula (Southern Baltic Sea). Arch. Hydrobiol. 134, 359-377.

Komárek, J. (2013). “Cyanoprokaryota. 3. Teil. Heterocystous Genera," in Süßwasserflora von Mitteleuropa, eds B. Büdel, G. Gärtner, L. Krienitz, and M. Schagerl (Heidelberg: Springer Spektrum), doi: 10.1007/978-3-8274-2737-3

Komárek, J. (2016). A polyphasic approach for the taxonomy of cyanobacteria: principles and applications. Eur. J. Phycol. 51, 346-353. doi: 10.1080/09670262. 2016.1163738
Komárek, J., and Anagnostidis, K. (1989). Modern approach to the classification system of cyanophytes, 4-nostocales. Algol. Stud. 56, 247-345.

Komárek, J., and Anagnostidis, K. (1999). "Cyanoprokaryota. 1. Teil, Chroococcales," in Süßwasserflora von Mitteleuropa, eds H. Ettl, G. Gärtner, H. Heynig, and D. Mollenhauer (Heidelberg: Spektrum Akademischer Verlag).

Komárek, J., and Anagnostidis, K. (2005). "Cyanoprokaryota. 2. Teil. Oscillatoriales," in Süßwasserflora von Mitteleuropa, eds B. Büdel, G. Gärtner, L. Krienitz, and M. Schagerl (Heidelberg: Elsevier GmbH Spektrum Akademischer Verlag).

Komárek, J., Kaštovk, J., and Jezberová, J. (2011). Phylogenetic and taxonomic delimitation of the cyanobacterial genus Aphanothece and description of Anathece gen. nov. Eur. J. Phycol. 46, 315-326. doi: 10.1080/09670262.2011. 606373

Komárek, J., Kaštovsk, J., Mares, J., and Johansen, J. R. (2014). Taxonomic classification of cyanoprokaryotes (cyanobacterial genera) 2014, using a polyphasic approach. Preslia 86, 295-335.

Komárková-Legnerová, J., and Cronberg, G. (1994). Planktic blue-green algae from lakes in South Scania, Sweden. Part I. Chroococcales. Algol. Stud. 72, 13-51.

Lampert, W., Rothhaupt, K. O., and von Elert, E. (1994). Chemical induction of colony formation in a green alga (Scenedesmus acutus) by grazers (Daphnia). Limnol. Oceanogr. 39, 1543-1550. doi: 10.4319/lo.1994.39.7.1543

Lange, E. (2014). "Potentially toxic cyanobacteria in winter plankton of the Curonian Lagoon, Baltic Sea," in Proceedings of the International Council for the Exploration of the Sea - Council Meeting 2014, Copenhagen, 6-7.

Lange, E. K. (2011). Structure and spatial distribution of winter phytoplankton of the Curonian Lagoon (Baltic Sea). Ekologija 57, 121-127. doi: 10.6001/ekologija. v57i3.1917

Larsson, U., Hajdu, S., Walve, J., and Elmgren, R. (2001). Baltic Sea nitrogen fixation estimated from the summer increase in upper mixed layer total nitrogen. Limnol. Oceanogr. 46, 811-820. doi: 10.4319/lo.2001.46.4.0811

Lopes, V. R., and Vasconcelos, V. M. (2011). Planktonic and benthic cyanobacteria of European brackish waters: a perspective on estuaries and brackish seas. Eur. J. Phycol. 46, 292-304. doi: 10.1080/09670262.2011.602429

López-Archilla, A. I., Moreira, D., López-García, P., and Guerrero, C. (2004). Phytoplankton diversity and cyanobacterial dominance in a hypereutrophic shallow lake with biologically produced alkaline pH. Extremophiles 8, 109-115. doi: 10.1007/s00792-003-0369-9

Marin, B., Nowack, E. C. M., and Melkonian, M. (2005). A plastid in the making: evidence for a second primary endosymbiosis. Protist 156, 425-432. doi: 10.1016/j.protis.2005.09.001

Michalak, A. M., Anderson, E. J., Beletsky, D., Boland, S., Bosch, N. S., Bridgeman, T. B., et al. (2013). Record-setting algal bloom in Lake Erie caused by agricultural and meteorological trends consistent with expected future conditions. Proc. Natl. Acad. Sci. U.S.A. 110, 6448-6452. doi: 10.1073/pnas. 1216006110

Moreno, J. L. (2003). "Fitoplancton," in Manual Para la Colecta, el Manejo y las Observaciones de Campo Para Bioindicadores de Calidad del Agua, eds G. De La Lanza-Espino and S. Hernández-Pulido (México: CNA/AGT EDITOR), 13-45.

Moreno-Ruíz, J. L. (2000). "Fitoplancton," in Organismos Indicadores de la Calidad del Agua y de la Contaminación, eds G. De La Lanza-Espino, S. HernándezPulido, and J. L. Carbajal-Pérez (Mexico: Instituto de Biología-UNAM), 43-108.

Moreno-Ruíz, J. L. (2005). "Fitoplancton," in Biodiversidad de Tabasco, eds J. S. Bueno-Soria and F. Álvarez-Noguera (México: Instituto de Biología-UNAM), 33-64.

Nasev, D., Nasev, S., and Guiard, V. (1978). Einige aspekte der qualitativen untersuchungen am phytoplankton in den boddengewässern des Darß und des zingst (südliche Ostsee). Wiss. Z. Univ. Rostock Math. Naturwiss. Reihe 27, 345-348.

Nawrocka, L., and Kobos, J. (2011). The trophic state of the Vistula Lagoon: an assessment based on selected biotic and abiotic parameters according to the Water Framework Directive. Oceanologia 53, 881-894. doi: 10.5697/oc. 53-3.881

Nübel, U., Garcia-Pichel, F., and Muyzer, G. (1997). PCR primers to amplify $16 S$ rRNA genes from cyanobacteria. Appl. Environ. Microbiol. 63, 3327-3332.

Oben, P. M., and Oben, B. O. (2006). Influence of nutrient concentrations on the seasonal abundance and distribution of Cyanophyceae in the coastal region of Mount Cameroon. Afr. J. Mar. Sci. 28, 25-31. doi: 10.2989/18142320609504130 
Olenina, I. (2013). Identification of Algae Species in the Curonian Lagoon. SUBMARINER Report 2/2013. Available at: http://www.submarinerproject.eu/index.php?option=com_jdownloads\&task=download.send\& catid $=78 \& \mathrm{~m}=0$

Oren, A. (2011). Cyanobacterial systematics and nomenclature as featured in the International Bulletin of Bacteriological Nomenclature and Taxonomy / International Journal of Systematic Bacteriology / International Journal of Systematic and Evolutionary Microbiology. Int. J. Syst. Evol. Microbiol. 61, 10-15. doi: 10.1099/ijs.0.018838-0

Oren, A., and Garrity, G. M. (2014). Proposal to change general consideration 5 and principle 2 of the international code of nomenclature of prokaryotes. Int. J. Syst. Evol. Microbiol. 64, 309-310. doi: 10.1099/ijs.0.059568-0

Padisák, J., Crosetti, L. O., and Naselli-Flores, L. (2009). Use and misuse in the application of the phytoplankton functional classification: a critical review with updates. Hydrobiologia 621, 1-19. doi: 10.1007/s10750-0089645-0

Paldavičienè, A., Mazur-Marzec, H., and Razinkovas, A. (2009). Toxic cyanobacteria blooms in the Lithuanian part of the Curonian Lagoon. Oceanologia 51, 203-216. doi: 10.5697/oc.51-2.203

Palinska, K. A., Liesack, W., Rhiel, E., and Krumbein, W. E. (1996). Phenotype variability of identical genotypes: the need for a combined approach in cyanobacterial taxonomy demonstrated on Merismopedia-like isolates. Arch. Microbiol. 166, 224-233. doi: 10.1007/s002030050378

Palinska, K. A., and Surosz, W. (2014). Taxonomy of cyanobacteria: a contribution to consensus approach. Hydrobiologia 740, 1-11. doi: 10.1007/s10750-0141971-9

Pankow, H. (1976). Taxonomische bemerkungen zu einigen algen aus den boddengewässern des Darß und des Zingst. Wiss. Z. Univ. Rostock Math. Naturwiss. Reihe 25, 255-262.

Pankow, H. (1990). Ostsee-Algenflora. Jena: Fischer.

Pankow, H., and Martens, B. (1973). Die Beziehungen der Kleinalgenflora der Darßer boddenkette (südliche Ostsee) zur qualität dieser gewässer. Wiss. Z. Univ. Rostock Math. Naturwiss. Reihe 22, 1147-1151.

Phlips, E. J., Badylak, S., and Lynch, T. C. (1999). Blooms of the picoplanktonic cyanobacterium Synechococcus in Florida Bay, a subtropical inner-shelf lagoon. Limnol. Oceanogr. 44, 1166-1175. doi: 10.4319/lo.1999.44.4.1166

Pilkaitytë, R. (2007). Spring-summer transition in the Curonian Lagoon (SE Baltic Sea) phytoplankton community. Transit. Water. Bull. 1, 39-47.

Rajaniemi-Wacklin, P., Rantala, A., Mugnai, M. A., Turicchia, S., Ventura, S., Komárková, J., et al. (2006). Correspondence between phylogeny and morphology of Snowella spp. and Woronichinia naegeliana, cyanobacteria commonly occurring in Lakes. J. Phycol. 42, 226-232. doi: 10.1111/j.1529-8817. 2006.00179.x

Reynolds, C. S., Huszar, V., Kruk, C., Naselli-Flores, L., and Melo, S. (2002). Towards a functional classification of the freshwater phytoplankton. Hydrobiologia 24, 417-428. doi: 10.1093/plankt/24.5.417

Rippka, R., and Herdman, H. (1992). Pasteur Culture Collection of Cyanobacterial Strains in Axenic Culture: Catalogue \& Taxonomic Handbook. Paris: Institute Pasteur.

Robertson, B. R., Tezuka, N., and Watanabe, M. M. (2001). Phylogenetic analyses of Synechococcus strains (cyanobacteria) using sequences of $16 \mathrm{~S}$ rDNA and part of the phycocyanin operon reveal multiple evolutionary lines and reflect phycobilin content. Int. J. Syst. Evol. Microbiol. 51, 861-871. doi: 10.1099/ 00207713-51-3-861

Rocap, G., Larimer, F. W., Lamerdin, J., Malfatti, S., Chain, P., Ahlgren, N. A., et al. (2003). Genome divergence in two Prochlorococcus ecotypes reflects oceanic niche differentiation. Nature 424, 1042-1047. doi: 10.1038/nature01947

Santos, R. M., Saggio, A. A., Silva, T. L. R., Negreiros, N. F., and Rocha, O. (2015). Short-term thermal stratification and partial overturning events in a warm polymictic reservoir: effects on distribution of phytoplankton community. Braz. J. Biol. 75, 19-29. doi: 10.1590/1519-6984.05313

Scanlan, D. J., Ostrowski, M., Mazard, S., Dufresne, A., Garczarek, L., Hess, W. R., et al. (2009). Ecological genomics of marine picocyanobacteria. Microbiol. Mol. Biol. Rev. 73, 249-299. doi: 10.1128/MMBR.00035-08

Schapira, M., Buscot, M., Pollet, T., Leterme, S. C., and Seuront, L. (2010). Distribution of picophytoplankton communities from brackish to hypersaline waters in a South Australian coastal lagoon. Saline Systems 6:2. doi: 10.1186/ 1746-1448-6-2
Schlie, C. (2009). Morphologische und Molekulare Taxonomie des chroococcalen Cyanobakterienplanktons der Darß Zingster Boddenkette. Diploma thesis, University of Rostock, Rostock.

Schoor, A., Selig, U., Geiß-Brunschweiger, U., Schaible, R., Schumann, R., Schubert, B., et al. (2008). Phytoplankton diversity and photosynthetic acclimation along a longitudinal transect through a shallow estuary in summer. Mar. Ecol. Prog. Ser. 364, 31-46. doi: 10.3354/meps07452

Schumann, R., Baudler, H., Glass, Ä., Dümcke, K., and Karsten, U. (2006). Longterm observations on salinity dynamics in a tideless shallow coastal lagoon of the Southern Baltic Sea coast and their biological relevance. J. Mar. Syst. 60, 330-344. doi: 10.1016/j.jmarsys.2006.02.007

Schumann, R., Hammer, A., Görs, S., and Schubert, H. (2005). Winter and spring phytoplankton composition and production in a shallow eutrophic Baltic lagoon. Estuar. Coast. Shelf Sci. 62, 169-181. doi: 10.1016/j.ecss.2004. 08.015

Schumann, R., Rentsch, D., Görs, S., and Schiewer, U. (2001). Seston particles along a eutrophication gradient in coastal waters of the Southern Baltic Sea: significance of detritus and transparent mucoid material. Mar. Ecol. Prog. Ser. 218, 17-31. doi: 10.3354/meps218017

Shih, P. M., Wu, D., Latifi, A., Axen, S. D., Fewer, D. P., Talla, E., et al. (2013). Improving the coverage of the cyanobacterial phylum using diversity-driven genome sequencing. Proc. Natl. Acad. Sci. U.S.A. 110, 1053-1058. doi: 10.1073/ pnas. 1217107110

Silva, C. A., Train, S., and Rodrigues, L. C. (2005). Phytoplankton assemblages in a Brazilian subtropical cascading reservoir system. Hydrobiologia 537, 99-109. doi: 10.1007/s10750-004-2552-0

Singh, P. K. (1973). Nitrogen fixation by the unicellular blue-green alga aphanothece. Arch. Mikrobiol. 92, 59-62. doi: 10.1007/BF00 409511

Sorokin, P. Y., Sorokin, Y. I., Boscolo, R., and Giovanardi, O. (2004). Bloom of picocyanobacteria in the Venice lagoon during summer-autumn 2001: ecological sequences. Hydrobiologia 523, 71-85. doi: 10.1023/B:HYDR. 0000033096.14267.43

Sorokin, Y. I., Sorokin, P. Y., and Ravagnan, G. (2006). Hypereutrophication events in the Ca'Pisani lagoons associated with intensive aquaculture. Hydrobiologia 571, 1-15. doi: 10.1007/s10750-006-0250-9

Stal, L. J., Albertano, P., Bergmann, B., von Bröckel, K., Gallon, J. R., Hayes, P. K., et al. (2003). BASIC: Baltic Sea cyanobacteria. An investigation of the structure and dynamics of water blooms of cyanobacteria in the Baltic Sea - responses to a changing environment. Cont. Shelf Res. 23, 1695-1714. doi: 10.1007/s13280015-0653-9

Stamatakis, K., Ludwig, T., and Meier, H. (2005). RAxML-III: a fast program for maximum likelihood-based inference of large phylogenetic trees. Bioinformatics 21, 456-463. doi: 10.1093/bioinformatics/bti191

Tamura, K., Stecher, G., Peterson, D., Filipski, A., and Kumar, S. (2013). MEGA6: molecular evolutionary genetics analysis version 6.0. Mol. Biol. Evol. 30, 27252729. doi: 10.1093/molbev/mst197

Tanabe, Y., Sano, T., Kasai, F., and Watanabe, M. M. (2009). Recombination, cryptic clades and neutral molecular divergence of the microcystin synthetase (mcy) genes of toxic cyanobacterium Microcystis aeruginosa. BMC Evol. Biol. 9:115. doi: 10.1186/1471-2148-9-115

Torgan, L. C., Pillar, V. D., and Niencheski, L. F. (2006). Phytoplankton associations of a coastal lagoon in South of Brazil. J. Coast. Res. SI 39, 1149-1151.

Wang, K., and Chen, F. (2004). Genetic diversity and population dynamics of cyanophage communities in the Chesapeake Bay. Aquat. Microb. Ecol. 2004, 105-116. doi: 10.3354/ame034105

Wasmund, N. (1997). Occurrence of cyanobacterial blooms in the Baltic Sea in relation to environmental conditions. Int. Rev. Ges. Hydrobiol. Hydrogr. 82, 169-184. doi: 10.1002/iroh.19970820205

Water Framework Directive (2000). Directive 2000/60/EC of the European Parliament and of the Council of 23 October 2000 establishing a framework for Community action in the field of water policy. Off. J. L 327, 1-73.

Waterbury, J. B. (1991). "The cyanobacteria: isolation, purification and identification," in The Prokaryotes, 2nd Edn, eds A. Balows, M. Dworkin, H. G. Schlegel, and H. Truper (Berlin: Springer), 2058-2078.

Willame, R., Boutte, C., Grubisic, S., Wilmotte, A., Komárek, J., and Hoffmann, L. (2005). Morphological and molecular characterization of 
planktonic cyanobacteria from Belgium and Luxembourg. J. Phycol. 42, 1312-1332. doi: $10.1111 / j .1529-8817.2006 .00284 . x$

Wilmotte, A., Van der Auwera, G., and De Wachter, R. (1993). Structure of the $16 \mathrm{~S}$ ribosomal RNA of the thermophilic cyanobacterium Chlorogloeopsis HTF ('Mastigocladus laminosus HTF') strain PCC7518, and phylogenetic analysis. FEBS Lett. 317, 96-100. doi: 10.1016/0014-5793(93)81499-P

Woese, C. R. (1987). Bacterial evolution. Microbiol. Rev. 51, 221-271.

WoRMS Editorial Board (2016). World Register of Marine Species. Belgium: World-wide electronic publication, Flanders Marine Institute (VLIZ). doi: 10.14 $284 / 170$

Xu, Y., Jiao, N., and Chen, F. (2015). Novel psychrotolerant picocyanobacteria isolated from Chesapeake Bay in the winter. J. Phycol. 51, 782-790. doi: 10.1111/ jpy.12318
Zuker, M. (2003). Mfold web server for nucleic acid folding and hybridization prediction. Nucleic Acids Res. 31, 3406-3415. doi: 10.1093/nar/gkg595

Conflict of Interest Statement: The authors declare that the research was conducted in the absence of any commercial or financial relationships that could be construed as a potential conflict of interest.

Copyright $(2017$ Albrecht, Pröschold and Schumann. This is an open-access article distributed under the terms of the Creative Commons Attribution License (CC BY). The use, distribution or reproduction in other forums is permitted, provided the original author(s) or licensor are credited and that the original publication in this journal is cited, in accordance with accepted academic practice. No use, distribution or reproduction is permitted which does not comply with these terms. 